\title{
IPO Stocks Performance Imperfection: A Review of Models and Empirical Works
}

\author{
Alex A. A. Bruce1, P. M. C. Thilakaratne ${ }^{2}$ \\ ${ }^{1}$ Lecturer of Finance, Department of Business Administration, Gombe State University, Nigeria and a Current PhD \\ Student of Finance with the Department of Accountancy, University of Kelaniya, Kelaniya, Sri Lanka \\ ${ }^{2}$ Senior Lecturer of Finance, Department of Accountancy and Director of Centre for Continuing and Distance \\ Education, University of Kelaniya, Kelaniya, Sri Lanka \\ Email: brucealex46@gmail.com, lal@kln.ac.lk
}

Received 28 January 2014; revised 28 February 2014; accepted 7 March 2014

Copyright @ 2014 by authors and Scientific Research Publishing Inc.

This work is licensed under the Creative Commons Attribution International License (CC BY).

http://creativecommons.org/licenses/by/4.0/

(c) (i) Open Access

\section{Abstract}

Performance of IPO stocks is determined by the returns on a firm's IPOs and other subsequent issues. Returns are derived from the price swings (volatility) as compared to the offer price so that a favourable swing indicates favourable returns and vice-versa. In the light of this, we review models and empirical works that try to explain these swings and their consequence on the IPOs performance to hypothesize that IPO stocks performance swing (return volatility) is inevitable as far as a real efficient market cannot exist except in a world of utopia. Evidences from the previous studies show that one reason or the other must be achieved or committed to get the IPO stocks marketed at the instance of the issue which subsequently keep influencing the same stocks even in the secondary market over a very long period of time even though at a minimum volatile rate but not completely eliminated. This is what we regard as stocks performance imperfection.

\section{Keywords}

IPOs; Stocks Performance Imperfection; Price Swings (Volatility); Efficient Market

\section{Introduction}

It will interest readers and capital market experts to know that IPO stocks performance assessment is and must always be favourable or unfavourable as long as there are externalities on the market for stocks. This is why stocks perform splendidly well, then experience dangerously price swings, then bubbles and finally crash. A wealth creating IPO stocks and other means of stocks issue should guarantee ideal returns as a form of security for investment over a long period of time if not for the entire life time of the stocks. By and large, an ideal and 
utopia scenario for a perfect stocks performance should be one that its returns fully reflect in its stable price. This assertion however, may not have or will never exist in real life practice.

We therefore, review theoretical and empirical breakthroughs on stocks performance whose imperfection has in most cases been attributed to either initial underpricing of IPOs, risks of macroeconomic factors or misinformation and fraud. In order words, the literatures build the pathway for our assumption that only an imperfect stocks performance can exist in this contemporary world of today's capital markets. From the literatures perused in this paper, we hypothesize that perfect stocks performance is in no way attainable in the capital market because of extraneous factors that seem impossible to erode so that only imperfection is the accommodating and manageable element to contend with. We also conclude that there is imperfect stocks return performance owing to the fact that the "Law of One Price" which states that "if two assets are equivalent in all economically relevant respects, then they should have the same market price" tend to be violated almost at all times. This is an indication of capital market irrationality. Stoll and Curly [1] document that initial public offerings (IPOs) have the tendency to provide abnormal returns to investors who purchased them at the initial offering.

Suffice to say that, the models and empirical works are discussed based on the performance of IPO stocks whose observations are attributed to underpricing of IPO stocks followed by the risk of macroeconomic factors and finally the misinformation and fraud influences. In this context therefore, we objectively seek to establish the fact that IPO stocks will continue to perform imperfectly in the face of all identified factors and model equations as long as the returns will always in most cases auto-correlate and lack independent of each other in a stochastic way, simply because these factor variables are constantly manipulated to cause returns variance.

The remainder of the paper is comprised of two sections. Section 2 discusses the imperfect stocks performance hypotheses which are grouped under five subsections; Subsection 2.1 presents the takes on the Random Walk Hypothesis while Subsection 2.2 takes on the Capital Asset Pricing Model (CAPM), the Arbitrage Pricing theory (APT) and the Autoregressive Conditional Heteroskedasticity (ARCH) Models. The IPO underpricing hypothesis is examined in Subsection 2.3; the macroeconomic factors hypotheses in Subsection 2.4 and the misinformation and fraud tendency hypotheses in Subsection 2.5. Finally, we conclude the paper in Section 3.

\section{The Imperfect Stocks Performance Hypothesis}

\subsection{The Random Walk and Wave Hypotheses}

Our proposition of the imperfect IPO stocks returns is not consistent with the Kendall's [2] Random Walk Hypothesis (hereafter RWH) which has the stock's price bearing on the movement made by the drunkard after being tipsy. He does not calculate nor determine where his footsteps stamp and which direction the next step will land him. This demonstrates the distance of movement $u_{t}$ at time $t$, and continues to walk indefinitely with gradual drifts farther and farther away from the bar where he drank. This is not the like manner with which IPO stock prices behave from the first day so that today's stock price is equal to yesterday's stock price plus a random shock, Gujarati et al., [3]. The RWH proposes random walk with three different emphases.

$\gamma_{t}$ Is random walk if:

$$
\Delta \gamma_{t}=\delta \gamma_{t-1}+\mu_{t}
$$

$\gamma_{t}$ Is random walk with drift if:

$$
\Delta \gamma_{t}=\beta_{1}+\delta \gamma_{t-1}+\mu_{t}
$$

and $\gamma_{t}$ is random walk with drift around a deterministic trend if:

$$
\Delta \gamma_{t}=\beta_{1}+\beta_{2 t}+\delta \gamma_{t-1}+\mu_{t}
$$

The RWH was further popularized in 1973 by Malkiel [4] in his book "A Random Walk down the Wall Street", that is now regarded as an investment classic. Random walk is a stock market theory that states that the past movement or direction of the price of a stock or overall market cannot be used to predict its future movement. This means that the stock price fluctuations are independent of each other and have the same probability distribution, but that over a period of time, prices maintain an upward trend. In short, random walk says that stocks take a random and unpredictable path. The chance of a stock's future price going up is the same as it going down so that a follower of random walk believes it is impossible to outperform the market without assuming additional risk. And that means that both technical and fundamental analyses are largely a waste of time and are still unproven in outperforming the markets. It is pertinent to note that these shocks could be negative or positive. 
In the early treatments of the efficient markets hypothesis (EMH), the statement that the current price of a security "fully reflects" available information was assumed to imply that successive price changes (or more usually, successive one-period returns) are independent. In addition, it was usually assumed that successive changes (or returns) are identically distributed, Fama [5]. However, both hypotheses constitute the random walk model which was modelled as

$$
r_{t}=\mu+\varepsilon_{t}
$$

So that the mean $(\mu)$ value of the returns is expectedly to be insignificantly different from zero while the epsilon $\left(\varepsilon_{t}\right)$ represents the random error term. However, because of the naive nature of the RWH to assume that stock returns follow random walk and so future expected returns cannot be determined using previous time series of information, the assumption has been debunked by several studies example Fama [5] and Magnus and Fosu [6] etc. This made the EMH by Fama [5] to expand on the information relevance for returns forecast using the RWH as:

$$
f\left(\frac{r_{j, t+1}}{\varnothing_{t}}\right)=f\left(r_{j, t+1}\right)
$$

In this model, the conditional and marginal probability distributions of an independent random variable are identical, that is, equal to zero. Although, the density function must be the same for all, yet it can ex ante returns in the model below to obtain the expected version:

$$
\epsilon\left(\frac{r_{j, t+1}}{\varnothing_{t}}\right)=\epsilon\left(r_{j, t+1}\right)
$$

On establishing these relationships, the EMH went ahead to dilute this into what is called the "fair game" model which states that the conditions of market equilibrium can be stated in terms of expected returns but says little about stochastic process generating returns. So that the new fair game has a serial covariance of zero to make the tests relevant for the expected return models, such that:

$$
\epsilon\left(x_{t+r} x_{t}\right)=\int_{x t} x_{t} \epsilon\left(\frac{x_{t+r}}{x_{t}}\right) f\left(x_{t}\right) \mathrm{d} x_{t}
$$

Note that the $\mathrm{f}$ is densities function while the $x_{t}$ is "fair game" given as:

$$
\epsilon\left(\frac{x_{t+r}}{x_{t}}\right)=0
$$

It is in this light that the Elliot and Richardson [7] (hereafter E-R) Wave theory state that rhythmic regularity had been the law of nature such that, all cycles-whether of tide, weather, or life had the capability of repeating themselves indefinitely so that two forces, one build up and the other tear down as a result of the movements. The market move forward in five waves and then decline in a series of three waves as E-R noted in an 80 year period with the below illustrative diagram (Figure 1).

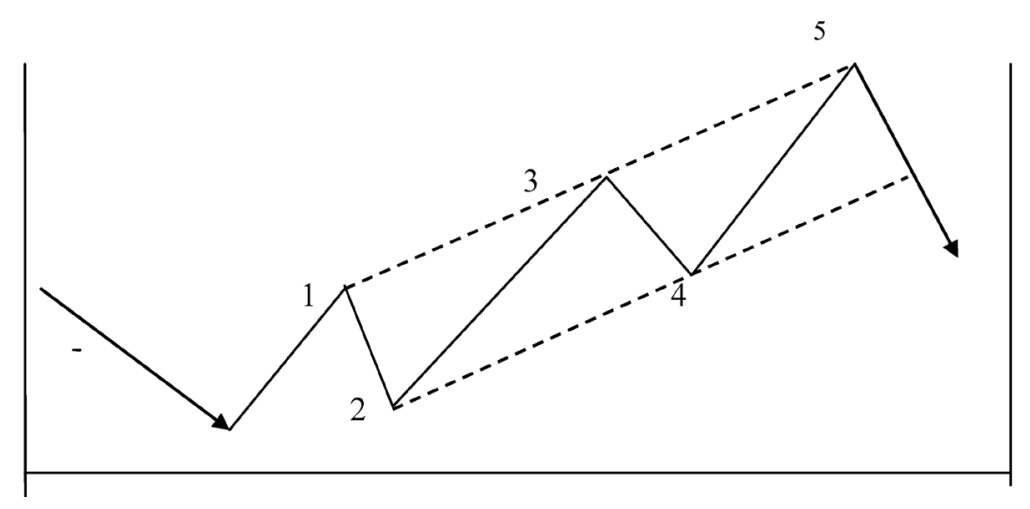

Figure 1. Wave patterns. 
They classified the waves into two-impulsive wave formation $(1,3,5)$ and the corrective wave $(2,4)$. These are difference between trend (impulsive wave) and a correction (sideways price movement with overlapping waves). E-R distinguished nine wave degrees, ranging from two centuries to hourly. These wave degrees are, grand super-cycle, super-cycle, cycle, primary, intermediate, minor, minute, minuettes, and sub-minuette. In theory, the numbers of waves' degrees are infinite, while it is difficult to spot more than four or five wave degrees in real practice. The application of the E-R Wave principle can only be possible by identifying the number of patterns/sub-patterns since the assumption is that a minimum of three waves will occur always, no matter what happens. Hence if investors concentrate on the $3^{\text {rd }}$ wave, either in an impulsive or corrective wave ${ }^{1}$, there will be a strong probability of making a profit. This principle expects the same pattern to evolve over and over again, to enable the investor forecast the markets ${ }^{2}$. This indicates that variations of returns are inevitable as long as the market waves will never stop, hence, the need for underwriters/analysts to do thorough work of identifying the market variables that breed return volatility via the waves put forward by the theory.

The Wave theory supports the application of the multifactor APT (Arbitrage Pricing Theory) and the GARCH (Generalized Autoregressive Conditional Heteroskedasticity) models since the causes of waves cannot be less than three given the contending factors in the stock market.

\subsection{The CAPM, APT and ARCH Models}

Ross' [8] and [9] APT asserts the existence of factor variables that impede on stocks and general assets prices to cause variability of returns but such variables were not completely identified by the theory just as the E-R Wave Theory which speculates that variability is inevitable, and comes like a wave pattern, usually correcting itself in the future (short and long-runs). These variability and waves are continuous and caused by factors that are believed to be both market-wide and firm-specific whose influences can be reduced or eliminated for the latter but the former is said to be completely uncontrollable. Before these, the Capital Asset Pricing Model (CAPM) of Sharpe [10], Lintner [11] and Treynor [12] instead device a means of ascertaining ex ante returns which of course came under criticisms, being very difficult to compute as it concerns expected returns emphasizing on risk-free rate, i.e. the pure time value of money $\left(r_{f}\right)$, the expected market return $\epsilon\left(r_{m}\right)$ and the beta coefficient $\left(\beta_{i}\right)$ being determinants of stocks expected returns $E\left(r_{i}\right)$, simplified as:

$$
\epsilon\left(r_{i}\right)=r_{f}+\beta_{i}\left[\epsilon\left(r_{m}\right)-r_{f}\right]
$$

where the beta is calculated as the covariance of asset return $i$ and its market return divided by the variance of the market return.

$$
\beta_{i}=\frac{\operatorname{Cov}\left(R_{i}, R_{m}\right)}{\sigma_{m}^{2}}
$$

And thus having the inability to identify in practice the factors responsible for shocks in stocks expected returns, the APT came into limelight to redefine mathematically a factor (s) equation that can accommodate conflicting determinants of stocks returns. But even with that, it as well provides little guidance concerning what factors (sources of risk) ought to result in risk premiums, Bodie et al., [13] to remedy for stocks performance imperfection. However, for the APT, Chen, Roll and Ross [14] identify several possible variables that might proxy for systematic factors such as growth rate in industrial production, changes in expected inflation measured by changes in short-term (T-bill) interest rates, unexpected inflation defined as the difference between actual and expected inflation, unexpected changes in risk premiums measured by the difference between the returns on corporate Baa-rated bonds and long-term government bonds and finally the unexpected changes in the term premium measured by the difference between the returns on long and short-term government bonds. So that the APT mathematically progressed from single factor usage of

$$
R_{t}=\epsilon\left(r_{t}\right)+\beta_{t} F+e_{t}
$$

\footnotetext{
${ }^{1}$ Market reaction to the signals of news announcements issued by seasoned firms is not completed immediately. However, in most cases, market prices adjust slowly to such news or signals, with trends extending over several months.

${ }^{2}$ Elliot Wave provides an effective method for trading on the stock market. Its patterns indicate where the market is heading, in what way (or structure) this will happen and under what circumstances the pattern will produce a stronger probability. Ranganatham, M. and Madhumathi, R. “Investment Analysis and Portfolio Management”. Dorling Kindersley (India) Pvt. Ltd, 346-348
} 
But because the APT is designed to accommodate multiple factors, Equation (11) can be rewritten as

$$
R_{t}=\epsilon\left(r_{t}\right)+\beta_{t} F+\beta_{t} G+\beta_{t} H+e_{t}
$$

where $R_{t}$ is the expected return on stock t, the $\beta_{t}$ being the coefficients and slope of the systematic variables (F, G and $\mathrm{H}$ ) and the $e_{t}$ representing the idiosyncratic variables defined as the error term. However, the model holds that, the $r_{t}$ will always maintain its previous value in a given period if there appears to be no macro shocks from the macro economic variables instead its value will only be determined by the firm-specific variables. This theory though gained acceptance yet could not adequately provide those systematic factors that influence assets.

The limitations of the APT in the area of factors identification and rate of variability of returns on assets pave way for the Autoregressive Conditional Heteroskedasticity (ARCH) models. This is because of the high rate of risk and uncertainty in the modern capital markets when considering their econometric time series which of course demanded a thorough study into their time varying variances and covariance. Engle [15] propounded the ARCH model to capture past data to distinct between the conditional and the unconditional second order moments as against the previous studies on conditional verses unconditional mean which usually indicates time invariant. Hence the ARCH model provides a very simple standard dynamic regression as

$$
\gamma_{t}=x_{t} \beta+\varepsilon_{t}
$$

where $x_{t}$ is a set of weak exogenous and lagged dependent variables and the $\varepsilon_{t}$ represents a Gaussian noise process (shocks).

$$
\frac{\varepsilon_{t}}{I_{t-1}} \sim N\left(0, \sigma^{2}\right)
$$

The ARCH (q) model is deficient because it omits and fails to account for a relevant regressor and non-linearity or serial correlation; it also omits the constant but subtracts the estimate of the unconditional variance $\left(\sigma^{2}\right)$ from the dependent variable and uses one half the explained sum of squares as a test statistics, Bollerslev et al., [16]. Because of these limitations to adequately accommodate more independent variables and to capture constants and linearity to assess the performance of stocks at intervals, the Generalized Autoregressive Conditional Heteroskedasticity (GARCH) model was developed by Bollerslev [17]. The model captures the thick tailed returns; volatility clustering and can readily modify to allow for several other stylized facts such as non-trading periods and predictable information releases, Bollerslev et al., [16].

$$
\sigma_{t}^{2}=a_{0}+a_{1} \varepsilon_{t-1}^{2}+a_{2} \sigma_{t-1}^{2}
$$

where

$a_{0}, a_{1}$, and $a_{2}$ are estimates from past data

$\sigma_{t-1}^{2}$ Is the most recent variance forecast

$\varepsilon_{t-1}^{2}$ Is most recent squared prediction error in market return.

However, because the GARCH also could not capture in clarity the effect of good and bad news affecting stocks performance, the Exponential GARCH (EGARCH) and the Threshold GARCH (TGARCH) came on board to capture the asymmetric shocks to the conditional variance. Nelson [18] Exponential GARCH takes the form of natural logarithm of the conditional variance so that it is allowed to vary over time as a function of the lagged error terms rather than the lagged squared errors. The EGARCH $(1,1)$ is writhen as:

$$
\ln h_{t}^{2}=\omega+\alpha\left[\varepsilon_{t}-\frac{1}{h t-1}\right]+\gamma\left[\varepsilon_{t}-\frac{1}{h t-1}\right]+\beta \ln h_{t-1}^{2}
$$

The y captures the asymmetric effect so that the conditional variance is always positive even if the parameter values are negative. Furthermore the Threshold GARCH of Glosten, Jagannathan and Runkle [19] modifies the original GARCH specifications using a dummy variable with the assumption that unexpected changes in the market returns have different effects on the conditional variance of the returns. Such that good news goes with an unforeseen increase contributing to the variance through the coefficient $\beta$ instead of an unexpected decrease which is presented as a bad news and contributes to the variance with the coefficient $\alpha+\mathrm{y}$, so that, if $\mathrm{y}>0$, the leverage effect exist and news impact is asymmetric if $y \neq 0$, Magnus \& Fosu, [6]. The TGARCH is, 


$$
h t=\omega+\alpha \varepsilon_{t-1}^{2}+\gamma \varepsilon_{t-1}^{2} \zeta_{t-1}+\beta h_{t-1}
$$

where $\zeta_{t-1}=1$, if $\varepsilon_{t-1}<0$, and $\zeta_{t-1}=0$, if $\varepsilon_{t-1}>0$.

It is obvious to not that the IPO stocks performance and generally equity stocks returns have consistently undergone series of studies to determine the ex ante and post ante returns yet, the volatility persist and locks in the stock market. The GARCH models are so many but all of them have not being able to eliminate as well as device appropriate methods to predict the IPO stocks returns with all certainty having known the factor-causes of volatility. In fact, it is expedient to also not that, the $\varepsilon_{t}$ is never at any point zero even if idiosyncratic variables are introduced in the regression, indicating a non-exhaustive variable determination. The several studies on IPOs using mostly the models above have indicated several of the factors responsible for the variability of the returns performance but the variability still persist and in most cases shows autocorrelation which means, the return series are never independent of each other.

\subsection{The IPO Underpricing Hypotheses}

Most of the theoretical research on IPOs focuses on explaining IPOs performance imperfection via underpricing and overpricing which lead to volatility of the stocks returns. Underpricing could be "a large positive gain to a new issue (relative to its offer price) immediately after listing”, Chan et al., [20] which is significantly larger than the average returns of the other days or overpricing otherwise. Possible reasons for underpricing may include self-interested investment bankers, Baron and Holmstrom, [21]; Baron, [22]; the "winner's curse" where the underwriter under-prices (discounts) IPOs to induce uninformed investors to purchase IPO shares, Rock, [23] and Beatty \& Ritter, [24]); lawsuit avoidance of Logue [25]; and Ibbotson [26] are credited to the idea of legal insurance or lawsuit avoidance hypothesis. The assumption here is that companies deliberately sell their stock at a discount to reduce the likelihood of future lawsuits from shareholders disappointed with the post-IPO performance of their shares, Tinic, [27]. On the other hand, there are signalling reasons where IPO under-pricing is a mechanism to signal the issuing firms' quality: with the assumption that the issuers are more aware of their firm values than the investors at the time of offering, Allen and Faulhaber, [28]; Grinblatt and Hwang, [29]; Welch, [30]; market incompleteness, book-building, and information-gathering marketing models, where usually the underwriter uses underpricing and rationing as devices to entice selected investors in a "road show" to truthfully reveal their information, Benveniste and Spindt, [31]; and informational cascades, Welch [32]. Evidence also suggests that in some countries IPO underpricing may be due to the regulatory environment, Loughran, Ritter, and Rydqvist, [33]; the partial adjustment model of Ibbotson et al. [34] suggest that underpricing may be the result of changes in the offer price between the filing of the preliminary prospectus and the final prospectus; the ownership dispersion model of Booth and Chua [35] is where IPOs are deliberately offered at a discount by the issuers because they want to create excess demand for their issue.

Furthermore, Logue [25] suggests that underwriter warrants create incentives for underwriters to deliberately set the offer price below its true market value, Mauer and Senbet [36] presents the market incompleteness model suggesting that market incompleteness results in IPOs being underpriced so that investors can be compensated for bearing diversifiable risk. The institutional lag model of Ritter [37] suggests that underpricing might be attributed to rising Stock markets between the fixing of the offer price and the first trading day. By and large, the foregoing brief description of IPOs mispricing informs us of the possible reasons for variances in stock returns indicatively suggesting a deliberate reasons for making stocks return performance uncoordinated to critically reflect the true value of the firm and thereby producing imperfection both in the short-run and the long-run.

\subsection{The Macroeconomic Factor Hypotheses}

Ross [8] and [9] models a theory called the Arbitrage Pricing Theory (hereafter APT) that assert the existence of factor variables that impede on stock returns and general assets returns to cause variability but such variables were not completely identified by the theory. APT assumes that there are factors that influence assets returns to systematically vary or deviate from their expected propositions, which in our current assertion automatically directly or indirectly causes IPO stocks performance imperfect. In trying to ascertain what causes returns on assets such as firm investments and securities to deviate from their forecasted or expected returns when displayed in the market, Ross was propelled to develop the APT which assumes that some macroeconomic variables exist within the circle of the market circumference which possess multifaceted nature of systematic risks upon whom 
all returns on assets are severely influenced leading to a very high uncontrollable volatility. The APT assumes that expected returns (i.e. stock performance) is always affected by macroeconomic factors that the firm may not be in the position to alter even when the investor tries to reduce his investment risks by diversifying in different asset portfolios. The APT uses arbitrage to mean a situation of uncompromised exploitation of security mispricing in such a way that risk-free profits can be earned. Ross assumes that, in order to prevent arbitrage, an asset's expected return must be a linear function of its sensitivity to those risk factors. This theory debunks the presence of arbitrage opportunities in efficient financial markets. But a problem arises such that under certain circumstances, arbitrage may not be possible for rational and well capitalised investors to correct mispricing very quickly. This is because strategies used to offset or eliminate mispricing are most often risky, costly and somehow restricted, Ross et al., [38]. Firm-specific risk, noise trader risk and implementation costs are usually the major obstacles. It is also note worthy to state that, the major agent of stocks varying performance (i.e., mispricing) could completely ignore all other factors including the macroeconomic factors and thereby cause a long time lingering effects on the returns.

A study of the South African stocks market by Chinzara [39] show that macroeconomic uncertainties significantly affect the stock market volatility such that exchange rate volatility, short-term interest rate volatility, and financial crises impacts very negatively on stocks returns with very little effects from variability in gold prices, oil prices and inflation rate. In his classical paper on the relationship between stock market volatility and volatility of real and nominal macroeconomic variables, Schwartz [40] concludes that movements in inflation and real output has weak predictive power on volatility of stock market and return.

Ross et al. [38] documenting on UK pound to US dollar exchange rate, state that foreign exchange rates have been relatively fixed and stable before the early 1970s when the Britton Woods agreement broke-down, given room to unpredictable exchange rate volatility controlled and determined by the market forces. Other than the early 1970s, exchange rates were fixed in most cases and significant changes rarely occur because importers and exporters could predict with relative certainty the future state of exchange rates. This means that the financial and economic activities are influenced by exchange rates fluctuations.

Olweny and Omondi [41] document that foreign exchange rate volatility significantly affects stock return volatility on the Nairobi Stock Exchange. In a study of a relationship between the Johannesburg stock market and foreign exchange rate, Hsing [42] observes that there is a positive relationship between stock returns and foreign exchange rate. Benita and Lauterbach [43] note that exchange rate volatility have real economic costs that affect price stability, firm profitability and the general economy's stability. Going by these findings, it is easier to clarify that foreign exchange rate volatility impact on the IPO stocks return variability because of its ability to impair on the general performance of the economy. This is because decisions on fiscal and monetary policies are dependent upon foreign exchange rate fluctuations and other macroeconomic factors.

Interest rate reduces or increases the attractiveness of investment opportunities ${ }^{3}$. By and large, it will be needless for investor to go for an investment asset if the rate of interest is very high, knowing that it has all the capabilities to reduce the present value of future cash flows and vice-versa. This is so because; interest rate determines the interest payments on investment assets. Hence they are key determinants of business investment expenditures. The primary function of interest rate is to assist the mobilization of financial resources and ensure efficient utilization of same in the promotion of growth and development, Ngugi \& Kabubo, [44].

Since interest rate promotes economic growth and development, it therefore, implies that it has positive impact on IPO stock returns, Chen et al., [14]. Although this could vary from different economies because, Chen et al. [45] observe in a study of Taiwan stocks market and found that interest rate has no significant effect on Taiwan Hotel stock return. Consistent with this observation, interest rate also had a negative relationship toward Singapore Hotel stock market, Chiang et al., [46].

There is a very great inter-woven relationship between interest rate and financial risk. For instance, Ross, Westerfield and Jordan [38] document that the most current example of financial risk effect is the collapse of the once-thriving US savings and loan (S\&L) industry which at a time was relatively simple because they accepted short-term deposits at lower interest rates and extended long-term, fixed rate home mortgage loans at higher rates which helped them spread profits; not until the interest rates volatility crept in suddenly, so that short-term interest rates became highly volatile, exceeding the long-term rates on various intervals by substantial amounts.

This made the S\&L industries business very complicated and loosing, because long-term mortgage borrowers

$\overline{3}$ Note that an increase in interest rates have the inbuilt mechanism that leads to increase in financing costs which invariably decrease revenues of firms and individual investors. 
stocked to their low-interest payments while the short-term depositors removed their funds ${ }^{4}$. The S\&L were forced to borrow more short-term funds at high interest rates believing to correct the trend but instead ended-up into higher default rates which was very unfamiliar to the S\&Ls. The clear note here is that, investors in most cases deposit their excess funds in anticipation for better investment opportunities, so that whenever, investment assets prove highly investable, they rush for it because of the interest rate associated.

Walsh [47] reveals that the changes in short-term interest rate that serves as the operational target for implementing monetary policy will affect aggregate spending decisions only if long-term real rates of interest are affected. He further narrates that while the use of interest rate-oriented policy reduces the importance of money demand in the transmission of policy actions to the real economy, it raises to prominence the role played by the term structure of interest rates. Some of the proponents of this expectations theory of term structure of interest rate are Shiller [48], and Campbell and Shiller [49] whose writings have impacted on the general outlook of short-term interest rate variations as they influence general investment and spending, given an effect on longterm rates of interest. This means that interest rate volatility sways investment patterns of investors.

When an economy is heated up, it results into high inflation rate. That is when the general price level tends to experience simultaneous increases rendering purchasing power almost worthless to acquire the same value of assets it originally could acquire. An economy becomes highly heated up, if the demand for consumption outstrips productivity. In a study of the Nigerian stock market, Yaya and Shittu [50] find that the previous inflation rates have significant effects on conditional stock market volatility. Changes in inflation rates, as measured by changes in these rates also have greater impact in predicting the stock market volatility in Nigeria.

These results concur with Fisher's effect in international stock market. Fisher [51 $]^{5}$ asserts that the nominal interest rate consists of a real rate plus the expected inflation rate. He stated that expected real rate of the economy is determined by the real factors such as productivity of capital and time preference of savers and is independent of the expected inflation rate. If Fisher effect holds, then there is no change in inflation and nominal stock returns since stock returns are allowed to hedge for inflation. Although, some opposed to Fisher's proposition, and claimed that the real rates of common stock return and expected inflation rates are independent and that nominal stock returns vary in one-to-one correspondence with expected inflation, yet the proposition is largely utilized by most financial economists.

It is observed by Bradley and Jordan [52] and Lowry and Schwert [53] that initial returns are explained partly by the initial returns of previous IPOs. In consistence with their work, Loughran and Ritter [54] and Lowry and Schwert [53] further maintain that initial returns are positively related to market-wide stock price increases before the IPO.

This means that prior to the IPO of a firm, the behaviour of prices of existing stock prices have very great impact on the new firm's value and the offer price of its IPOs. The knowledge acquired on the prices of other existing stocks is a product of adequate information that trickles down the lain to help determine the worth of the issuing firm and other related firms' stocks that have almost the same capacity and value.

The release of macroeconomic news or periods of heavy trading by the central bank could escalate fixed income and foreign exchange volatilities which in-turn affect stocks returns volatility, Harvey \& Huang, [55] [56]. Consistent to these assertions, Harris [57], Baillie and Bollerslev [58], Gerity and Mulherin [59], Engle and McFadden [60] and several others indicate that volatility is typically much higher at the open and close ${ }^{6}$ of stock and foreign exchange trading than during the middle of the day. The issue size of IPOs is typically small and the underwriters, often facing excess demand, ration new issues to their regular clients, who constitute a small subset of potential investors, Benveniste \& Spindt, [31]; Benveniste \& Wilhelm, [61]; and Spatt \& Srivastava, [62].

\subsection{The Misinformation and Fraud Tendency Hypotheses}

Povel, Singh and Winton [63] suggest that the incidence of fraud should be a hump-shaped function of investor believes about business conditions; peaking when investors believe conditions is good, but not extremely good. Which means that, investor believes about business conditions influence investor monitoring intensity which in

\footnotetext{
${ }^{4}$ Although there were other economic and political factors that contributed to the disaster, but the most root cause was the high rate of interest volatility on the short-run loans at the time.

${ }^{5}$ Because investors of course are ultimately concerned with what they can buy with their money, they require some sort of compensation for inflation, hence Irvin Fisher demonstrated a quickening formulae to handle such situation as thus: $1+R=(1+r)(1+h)$, where $R=$ Nominal interest rate; $r=$ Real interest rate; and $h=$ Inflation rate.

${ }^{6}$ The increase in volatility at the open partly reflects information accumulated and concealed while the market was closed.
} 
turn affects managerial fraud incentives on stocks. This is investor believe hypothesis that models fraud increase/decrease during IPOs trading to the rate of investors' believe on whether business conditions are good or bad to determine intensity of monitoring information on the issuing firm. On the other hand, the allocation of IPO shares can be used as a bribe (fraud), Wang et al., [64]; Ritter, [65]).

According to Bodie et al. [13], the scandals of 2000-2002 in the US centred largely on three broad practices: allocation of shares in IPOs, tainted securities research and recommendations put out to the public, and, probably most important, misleading financial statements and accounting practices. They further elaborated that, the SEC's Regulation FD (for Fair Disclosure), introduced in 2000, prohibit firms from divulging material information to one outside group (e.g. stock analysts) before making it available to the entire market. In addition to settle charges brought by New York Attorney General concerning their publication of biased stock research as a quid pro quo for IPO allocations and investment banking contracts, major investment banks (Citigroup, CSFB, Morgan Stanley, Goldman, Sachs, and Merrill Lynch) agreed in late 2002 to pay $\$ 900$ million in penalties, contribute over \$450 million to finance independent stock research and provide \$85 million to fund investor education programs. The agreement also lays out guidelines designed to fence off stock research from the investment banking side of the firm. For example, the firms have agreed to remove the link between analysts' compensation and the amount of investment banking business they bring into the firm and to bar analysts from participating in IPO allocations road-shows. The accord also limits, "Spinning" the practice of awarding IPO allocations to corporate executives who can reward underwriters with future investment banking business.

Information need is always inadequate despite the level of information sharing. Solomon [66] evidence that media coverage affects the price response to news announcements such that greater coverage of positive news stories raises investor expectations of future profitability, leading to price increases in the short-term and lower returns in the future around earnings announcements. He also suggests that investors rely on the media to help them process information and decide which stories are economically important. The investors in the CM are the demand for the IPO stocks hence available and accessible information produces the required demand for the IPOs. Inadequate information on the performance of the intending firm going public is an abysmal sign of failure in the form of underpricing to underwriters at the IPO road shows which metamorphose into high volatile initial returns and lower long-term returns. The information need is very vital at the initial stage of IPOs pricing. By this the IPOs price can be said to be underpriced, priced at par, or overpriced.

\section{Conclusions}

It is evident that IPOs performance imperfection persists in all stocks markets whether they are offered via the traditional firm-commitment offering or auction. This is because even in markets like Japan where most IPOs are offered via auction still experience some sort of returns volatility even though at a very minimal level compared to what is obtainable in the US and other markets, most of whose offerings are through the traditional firm-commitment offering. This means that the auction method of IPO offering has not been able to eliminate the IPOs initial returns volatility and inconsistencies despite the lower or absence of mispricing during and after the offer. Furthermore, most studies (Fisher, [51]; Gabriel, [67]; Bradley \& Jordan, [52]; Lowry \& Schwert, [53]; Chiang et al., [46]; Hsing, [42]; Olweny \& Omondi, [41] etc.) that identified macroeconomic factors such as inflation, foreign exchange, and interest rates volatility as well as variability of existing stocks prices of other firms have shown either positive or negative influences on the IPOs initial returns volatility. By and large, unknown gaps seem to be glaring, with auto-correlation, dependent of stochastic series which poses serious riskeffect on IPOs performance irrespective of the market status. Markets such as the US tend to experience similar volatility despite its position of efficiency. The evidence shows with Loughran et al.'s [68] updates and the trends of reviews of the decade of bubbles on the Wall Street just as information asymmetry tend to communicate terribly to stocks performance as investors react to financial announcements, Huang [69] and business cycle risks and financial crisis, Schwert [70].

We therefore advocate that the IPO stocks performance is and will always be imperfect as long as the systematic and firm-specific variables have not been completely identified, or somewhat manipulated, to create more idiosyncratic shocks until they are really identified in totality; we are not yet good at it. The error term of all the models usually gives a value for unidentified shocks yet unknown and therefore needs further intensive research focusing on developed and emerging stock markets otherwise we still operate an imperfect IPO stocks returns performance, all things being equal. 


\section{References}

[1] Stoll, H.R. and Curley, A.J. (1970) Small Business and the New Issues Market for Equities. Journal of Financial and Quantitative Analysis, 309-322. http://dx.doi.org/10.2307/2329998

[2] Kendall, M. (1953) The Analysis of Economic Time Series, Part I: Prices. Journal of the Royal Statistical Society, 96, 1953.

[3] Gujarati, D.N., Porter, D.C. and Gunasekar, S. (2009) Basic Econometrics. 5th Edition, Tata_McGraw-Hill Education private Ltd., New Delhi, 784.

[4] Malkiel, B. (1996) A Random Walk down the Wall Street. 6th Edition, W. W Norton, New York.

[5] Fama, E.F. and MacBeth, J.D. (1973) Risk, Return, and Equilibrium: Empirical Tests. Journal of Political Economy, 81, 607-636. http://dx.doi.org/10.1086/260061

[6] Magnus, F.J. and Fosu, O.-T.E. (2006) Modelling and Forecasting Volatility of Returns on the Ghana Stock Exchange Using GARCH Models. American Journal of Applied Sciences, 3, 2042-2048. http://dx.doi.org/10.3844/ajassp.2006.2042.2048

[7] Elliot, J.D. and Richardson, G. (1976) The Association between Insider Trading and Information Announcements. Journal of Economics, 15, 521-536.

[8] Ross, S.A. (1976) The Arbitrage Theory of Capital Asset Pricing. Journal of Economic Theory, 13, 341-360. http://dx.doi.org/10.1016/0022-0531(76)90046-6

[9] Ross, S.A. (1976) Return, Risk and Arbitrage. In: Friend, I. and Bicksler, J., Eds., Risk and Return in Finance, Ballinger, Cambridge.

[10] Sharpe, W.F. (1964) Capital Asset Prices: A Theory of Market Equilibrium under Conditions of Risk. Journal of Finance, XIX, 425-442.

[11] Lintner, J. (1965) The Valuation of Risk Assets and the Selection of Risky Investments in Stock portfolios and Capital Budgets. Review of Economics and Statistics, XLVII, 13-37. http://dx.doi.org/10.2307/1924119

[12] Treynor, J.L. (1965) How to Rate Management of Investment Funds. Harvard Business Review, 43, 63-75.

[13] Bodie, Z., Kane, A., Marcus, A.J. and Mohanty, P. (2005) Investments. 6th Edition, Tata McGraw-Hill Publishing Company, New Delhi.

[14] Chen, N., Roll, R. and Ross, S.A. (1986) Economic Forces and the Stock Market. Journal of Business, 59, $383-403$. http://dx.doi.org/10.1086/296344

[15] Engle, R.F. (1982) Autoregressive Conditional Heteroskedasticity with Estimates of the Variance of UK Inflation. Econometrica, 50, 987-1008. http://dx.doi.org/10.2307/1912773

[16] Bollerslev, T., Engle, R.F. and Nelson, D.B. (1994) ARCH Models. In: Engle, R.F. and Mcfadden, D.L., Eds., Handbook of Econometrics, Elsevier Science, 2959-3037.

[17] Bollerslev, T. (1986) Generalized Autoregressive Conditional Heteroskedasticity. Journal of Econometrics, 31, 307327. http://dx.doi.org/10.1016/0304-4076(86)90063-1

[18] Nelson, D.B. (1991) Conditional Heteroskedasticity in Asset Returns: A New Approach. Econometrica, 59, $347-370$. http://dx.doi.org/10.2307/2938260

[19] Glosten, L.R., Jagannathan, R. and Runkle, D. (1993) On the Relation between the Expected Value and the Volatility of the Nominal Excess Return on Stocks. Journal of Finance, 48, 1779-1801. http://dx.doi.org/10.1111/j.1540-6261.1993.tb05128.x

[20] Chan, K., Wang, J. and Wei, K.C.J. (2003) Underpricing and Long-term Performance of IPOs in China. Journal of Corporate Finance, 10, 409-430. http://dx.doi.org/10.1016/S0929-1199(03)00023-3

[21] Baron, D. and Holmstrom, B. (1980) The Investment Banking Contract for New Issues under Asymmetric Information: Delegation and the Incentive Problem. Journal of Finance, 35, 1115-1138. http://dx.doi.org/10.1111/j.1540-6261.1980.tb02199.x

[22] Baron, D. (1982) A Model of the Demand for Investment Banking Advising and Distribution Services for New Issues. Journal of Finance, 37, 955-976. http://dx.doi.org/10.1111/j.1540-6261.1982.tb03591.x

[23] Rock, K. (1986) Why New Issues Are Under-Priced. Journal of Financial Economics, 15, 187-212. http://dx.doi.org/10.1016/0304-405X(86)90054-1

[24] Beatty, R.P. and Ritter, J.R. (1986) Investment Banking, Reputation, and the Underpricing of Initial Public Offerings. Journal of Financial Economics, 15, 213-232. http://dx.doi.org/10.1016/0304-405X(86)90055-3

[25] Logue, D. (1973) On the Pricing of Unseasoned Equity Issues: 1965-1969. Journal of Financial and Quantitative Analysis, 8, 91-103. http://dx.doi.org/10.2307/2329751 
[26] Ibbotson, R.G. and Jaffe, J.F. (1975) Hot Issue Markets. Journal of Finance, 30, 1027-1042.

[27] Tinic, S.M. (1988) Anatomy of Initial Public Offerings of Common Stock. Journal of Finance, 43, 789-822.

[28] Allen, F. and Faulhaber, G.R. (1989) Signalling by Underpricing in the IPO Market. Journal of Financial Economics, 23, 303-323. http://dx.doi.org/10.1016/0304-405X(89)90060-3

[29] Grinblatt, M. and Hwang, C.Y. (1989) Signalling and the Pricing of New Issues. Journal of Finance, 44, 393-420. http://dx.doi.org/10.1111/j.1540-6261.1989.tb05063.x

[30] Welch, I. (1989) Seasoned Offerings, Imitation Cost, and the Underpricing of Initial Public Offerings. Journal of Finance, 44, 421-448. http://dx.doi.org/10.1111/j.1540-6261.1989.tb05064.X

[31] Benveniste, L.M. and Spindt, P.A. (1989) How Investment Bankers Determine the Offer Price and Allocation of New Issues. Journal of Financial Economics, 24, 343-362. http://dx.doi.org/10.1016/0304-405X(89)90051-2

[32] Welch, I. (1992) Sequential Sales, Learning, and Cascades. Journal of Finance, 47, 695-732. http://dx.doi.org/10.1111/j.1540-6261.1992.tb04406.x

[33] Loughran, T., Ritter, J.R. and Rydqvist, K. (1994) Initial Public Offerings: International Insights. Pacific-Basin Finance Journal, 2, 165-199. http://dx.doi.org/10.1016/0927-538X(94)90016-7

[34] Ibbotson, R.G., Sindelar, J.L. and Ritter, J.R. (1988) Initial Public Offerings. Journal of Applied Corporate Finance, 1, 37-45. http://dx.doi.org/10.1111/j.1745-6622.1988.tb00164.x

[35] Booth, J. and Chua, L. (1995) Ownership Dispersion, Costly Information, and IPO Underpricing. Journal of Financial Economics, 41, 291-310. http://dx.doi.org/10.1016/0304-405X(95)00862-9

[36] Mauer, D.C. and Senbet, L.W. (1992) The Effect of the Secondary Market on the Pricing of Initial Public Offerings: Theory and Evidence. Journal of Financial and Quantitative Analysis, 24, 55-79. http://dx.doi.org/10.2307/2331298

[37] Ritter, J.R. (1984) The “Hot Issue” Market of 1980. Journal of Business, 57, 215-240. http://dx.doi.org/10.1086/296260

[38] Ross, S.A., Westerfield, R.W. and Jordan, B.D. (2010) Fundamentals of Corporate Finance. Tata McGraw Hill Education, Inc., New York.

[39] Chinzara, Z. (2010) Macroeconomic Uncertainty and Emerging Market Stock Market Volatility: The Case for South Africa. Working Paper, Rhodes University, Grahamstown.

[40] Schwert, G.W. (1989) Why Does Stock Market Volatility Change over Time? Journal of Finance, 44, 1115-1153. http://dx.doi.org/10.1111/j.1540-6261.1989.tb02647.x

[41] Olweny, T. and Omondi, K. (2011) The Effects of Macro-Economic Factors on Stock Return Volatility in the Nairobi Stock Exchange. Economic and Finance Review, 1, 34-48.

[42] Hsing, Y. (2011) The Stock Market and Macroeconomic Variables in a BRICS Country and Policy Implications. International Journal of Economics and Financial Issues, 1, 12-18.

[43] Benita, G. and Lauterbach, B. (2007) Policy Factors and Exchange Rate Volatility: Panel Data Verses a Specific Country Analysis. Bank of Israel, Foreign Exchange Activity Department, Jerusalem.

[44] Ngugi, R.W. and Kabubo, J.W. (1998) Financial Sector Reforms and Interest Rate Liberalization: The Kenya Experience. African Economic Research Consortium, 72.

[45] Chen, M.H., Kim, W.G. and Kim, H.J. (2005) The Impact of Macroeconomic and Non-Macroeconomic Forces on Hotel Stock Returns. Hospitality Management, 24, 243-258. http://dx.doi.org/10.1016/j.ijhm.2004.06.008

[46] Chiang, L.C. and Kee, H.T. (2009) Macro-Economic and Non-Macroeconomic Variables Link to Singapore Hotel Stock Returns. Oxford Business and Economic Conference Program, Oxford, 24-26 June 2009.

[47] Walsh, C.E. (2010) Monetary Theory and Policy. 3rd Edition, MIT Press, Cambridge.

[48] Shiller, R.J. (1990) The Term Structure of Interest Rates. In: Friedman, B.M. and Hahn, F.H., Eds., Handbook of Monetary Economics, North-Holland, Amsterdan, 626-722.

[49] Campbell, J.Y. and Shiller, R.J. (1991) Yield Spreads and Interest Rate Movements: A Bird’s Eye View. Review of Economic Studies, 58, 495-514. http://dx.doi.org/10.2307/2298008

[50] Yaya, O.S. and Shittu, O.I. (2010) On the Impact of Inflation and Exchange Rate on Conditional Market Volatility: A Re-Assessment. American Journal of Scientific and Industrial Research, 1, 115-117. http://dx.doi.org/10.5251/ajsir.2010.1.2.115.117

[51] Fisher, I. (1930) The Theory of Interest. Macmillan, New York.

[52] Bradley, D.J. and Jordan, B.D. (2002) Partial Adjustment to Public Information and IPO Underpricing. Journal of Financial and Quantitative Analysis, 37, 595-616. http://dx.doi.org/10.2307/3595013

[53] Lowry, M. and Schwert, G.W. (200) Is the IPO Pricing Process Efficient? Journal of Financial Economics, 71, 3-26. 
http://dx.doi.org/10.1016/S0304-405X(03)00205-8

[54] Loughran, T. and Ritter, J.R. (2002) Why Don't Issuers Get Upset about Leaving Money on the Table in IPOs? Review of Financial Studies, 15, 413-443. http://dx.doi.org/10.1093/rfs/15.2.413

[55] Harvey, C.R. and Huang, R.D. (1991) Volatility in the Foreign Currency Futures Market. Review of Financial Studies, 4, 543-569. http://dx.doi.org/10.1093/rfs/4.3.543

[56] Harvey, C.R. and Huang, R.D. (1992) Information Trading and Fixed Income Volatility. Unpublished Manuscript, Department of Finance, Duke University, Durham.

[57] Harris, L. (1986) A Transaction Data Study of Weekly and Intra-Daily Patterns in Stock Returns. Journal of Financial Economics, 16, 99-117. http://dx.doi.org/10.1016/0304-405X(86)90044-9

[58] Bollerslev, T. and Baillie, R. (1991) Intra Day and Inter Market Volatility in Foreign Exchange Rates. Review of Economic Studies, 58, 565-585. http://dx.doi.org/10.2307/2298012

[59] Gerity, M.S. and Mulherin, J.H. (1992) Trading Halts and Market Activity: An Analysis of Volume at the Open and Close. Journal of Finance, 47, 1765-1784. http://dx.doi.org/10.1111/j.1540-6261.1992.tb04682.x

[60] Engle, R.F. and Mcfadden, D.L. (1994) Hand-Book of Econometrics. Elsevier Science, Amsterdam.

[61] Benveniste, L.M. and Wilhelm, W.J. (1990) A Comparative Analysis of IPO Proceeds under Alternative Regulatory Environments. Journal of Financial Economics, 28, 173-207. http://dx.doi.org/10.1016/0304-405X(90)90052-2

[62] Spatt, C. and Srivastava, S. (1991) Pre-Play Communication, Participation Restrictions, and Efficiency in Initial Public Offerings. Carnegie-Mellon University, Pittsburghers.

[63] Povel, P., Singh, R. and Winton, A. (2007) Booms, Busts, and Fraud. Review of Financial Studies, 20, 1219-1254. http://dx.doi.org/10.1016/0304-405X(90)90052-2

[64] Wang, T.Y., Winton, A. and Yu, X.Y. (2010) Corporate Fraud and Business Conditions: Evidence from IPOs. The Journal of Finance, 62, 2255-2292.

[65] Ritter, J.R. (2004) Differences between European and American IPO Markets. European Financial Management, 9, 421-434. http://dx.doi.org/10.1111/1468-036X.00230

[66] Solomon, D.H. (2012) Selective Publicity and Stock Prices. The Journal of Finance, 67, 599-637.

[67] Ajao, M.G. (2012) Inflation, Financial Openness, Exchange Rate, and Stock Market Volatility. Indian Journal of Economics and Business, 11.

[68] Loughran, T., Ritter, J.R. and Rydqvist, K. (2013) Initial Public Offerings: International Insights. Pacific-Basin Finance Journal, 2, 165-199.

[69] Huang, X. (2004) China Stock Price Reactions to Financial Announcements: Evidence from Segmented Markets. Managerial Finance, 30, 62-73. http://dx.doi.org/10.1108/03074350410768976

[70] Schwert, G.W. (1989) Business Cycles, Financial Crises, and Stock Volatility. Carnegie Rochester Conference Series on Public Policy, 31, 83-125. 